\title{
Common Proteomic and Genomic Contribution to Ischemic Brain Damage and Alzheimer's Disease
}

\author{
Ryszard Pluta ${ }^{1}$ - Marzena Ułamek-Kozioł ${ }^{1,2}$ - Sławomir Januszewski ${ }^{1}$ • \\ Stanisław J. Czuczwar ${ }^{3}$ \\ ${ }^{1}$ Laboratory of Ischemic and Neurodegenerative Brain Research, Mossakowski Medical \\ Research Centre, Polish Academy of Sciences, Warsaw, Poland; ${ }^{2}$ First Department of \\ Neurology, Institute of Psychiatry and Neurology, Warsaw, Poland; ${ }^{3}$ Department of \\ Pathophysiology, Medical University of Lublin, Lublin, Poland
}

Author for correspondence: Ryszard Pluta, Laboratory of Ischemic and Neurodegenerative Brain Research, Mossakowski Medical Research Centre, Polish Academy of Sciences, 02-106 Warsaw, Pawińskiego 5 Str., Poland. Email: pluta@imdik.pan.pl Doi: http://dx.doi.org/10.15586/alzheimersdisease.2019.ch4

\begin{abstract}
Ischemic brain damage is associated with the deposition of folding proteins, such as all fragments of the amyloid protein precursor and tau protein, in the intra- and extracellular spaces of neurons. In this chapter, we summarize the protein changes associated with Alzheimer's disease and their gene expression (amyloid protein precursor and tau protein) after cerebral ischemia and their role in the ischemic etiology of Alzheimer's disease. Recent advances in understanding the ischemic etiology of Alzheimer's disease have revealed dysregulation of amyloid protein precursors, $\beta$-secretase, presenilin 1 and 2 , autophagy, mitophagy, apoptosis, and tau protein genes after ischemic brain injury. However, reduced expression of mRNA of the $\alpha$-secretase in cerebral ischemia causes neurons to be less resistant to injury. In this chapter, we present the latest evidence that Alzheimer's diseaserelated proteins and their genes play a key role in brain damage with ischemiareperfusion and that ischemic episode is an essential and leading provider of Alzheimer's disease development. Understanding the underlying processes of linking Alzheimer's disease-related proteins and their genes in brain ischemia
\end{abstract}

In: Alzheimer's Disease. Thomas Wisniewski (Editor), Codon Publications, Brisbane, Australia. ISBN: 978-0-646-80968-7; Doi: http://dx.doi.org/10.15586/alzheimersdisease.2019

Copyright: The Authors.

License: This open access article is licensed under Creative Commons Attribution 4.0 International (CC BY 4.0). https://creativecommons.org/licenses/by-nc/4.0/ 
injury with the risk of developing Alzheimer's disease will provide the most significant goals for therapeutic development to date.

Keywords: Alzheimer's disease; amyloid; brain ischemia; secretases; tau protein

\section{INTRODUCTION}

Newer studies show that brain ischemia with reperfusion can be associated with a fully developed Alzheimer's disease $(1,2)$. It is generally suggested that cerebral ischemia triggers Alzheimer's disease, and an ischemic change in the permeability of the blood-brain barrier additionally causes amyloid transportation from the blood to the brain, and this is the last element that causes the fullbloom sporadic Alzheimer's disease (3, 4). Ischemic human stroke and experimental ischemia-reperfusion brain injury are serious, life-threatening neuropathological episodes with severe complications such as post-ischemic cognitive impairment and physical disability (5-12). The evidence to date suggests that there is a potential compatibility among neuropathogenesis of brain ischemia and Alzheimer's disease. First, clinical observations have shown that Alzheimer's disease is a contributing factor to the development of ischemic brain damage and vice versa (13). Second, ischemic brain injury and Alzheimer's disease have the same risk factors like hypertension, hyperlipidemia, diabetes, and age. Third, experimental ischemia-reperfusion brain injury produces a stereotypical pattern of selective death/loss of neurons in the hippocampus with severe brain atrophy, which is similar to the neuropathology observed in Alzheimer's disease, indicating active, slowly progressive neuropathological processes (14-18). Fourth, inflammatory changes appear to play a key role in the progression of brain ischemia and Alzheimer's disease (19). Fifth, the data indicate that ischemic brain damage can cause the pathology of proteins typical for Alzheimer's disease by inducing the generation and deposition of the $\beta$-amyloid peptide and other fragments of amyloid protein precursor $(16,20-22)$. Finally, studies show that tau protein dysfunction also plays a key role in regulating brain ischemiareperfusion episodes (23-33). Together, these results point to common proteomic and genomic factors in ischemic brain injury and Alzheimer's disease in the neuropathological processes.

In this chapter, we present the current knowledge about the dysregulation of genes involved in the amyloidogenic processing of the amyloid protein precursor, which is associated with the generation of the $\beta$-amyloid peptide in the brain after ischemia. In addition, we pay attention to whether the signal pathway of the amyloid protein precursor is involved in the induced ischemic death of neurons in the $\mathrm{CAl}$ area of the hippocampus and medial temporal cortex. Also, we take into account the importance of ischemic gene expression associated with Alzheimer's disease, such as autophagy, mitophagy, and apoptosis during clinical onset, progression and maturation of brain injury after ischemia in the etiology of Alzheimer's disease. With regard to the latest exciting discoveries after brain ischemia injury, we combine data from the proteomic and genomic point of view. In recent years, several researchers have documented that brain ischemia-reperfusion episode is an important element in the development of Alzheimer's disease and plays a key role in proteomic and genomic (e.g., amyloid protein precursor, amyloid 
processing secretases, autophagy, mitophagy, caspase 3 , and tau protein) changes of this disorder $(1,2,31)$. Below we summarize the latest evidence that Alzheimer's disease-related proteins and their genes play an essential role in brain ischemiareperfusion injury, and ischemic episode is a necessary and most important supplier for the start and progress of the full development of sporadic Alzheimer's disease.

\section{AMYLOID STAINING AND BLOOD LEVEL AFTER BRAIN ISCHEMIA}

Although a significant progress has been made in research on the pathogenicity of amyloid in Alzheimer's disease, the underlying molecular amyloid machinery affecting neurodegeneration after ischemic brain injury is unclear. Herein we present the existing facts regarding amyloidogenic processing of the amyloid protein precursor into amyloid during brain injury due to ischemia and reperfusion, which is associated with the production and accumulation of the $\mathrm{N}$ - and C-terminal of amyloid protein precursor and amyloid in the brain. The appearance of an elevated level of $\beta$-amyloid peptide in the blood and its staining in the brain after ischemic injury sheds new light on a better understanding of the role of amyloid in the development of neurological deficits following an ischemic episode.

\section{In animals}

Different fragments of the amyloid protein precursor staining were observed in the extra- and intracellular spaces after experimental ischemic brain injury $(15,20,34-37)$. In animals that survived up to 6 months after brain ischemia with recirculation in the extracellular space of the hippocampus, brain cortex, white matter, and around the lateral ventricles, the $\mathrm{N}$ - and C-terminal deposits of the amyloid protein precursor and the $\beta$-amyloid peptide were observed $(16,20)$. The accumulation of different parts of the amyloid protein precursor in various cells, such as the neuronal, glial, microglia, oligodendrocyte, endothelial, pericyte, and ependymal cells, has also been found (15, 20, 38-42). Especially astrocytes around microvessels showed intense staining of many very long, thin processes that adhered to or embraced capillaries. More than 6 months of survival after cerebral ischemia, only the C-terminal staining of the amyloid protein precursor and the $\beta$-amyloid peptide was observed (16). Accumulation of $\beta$-amyloid peptide in response to transient focal ischemic brain injury does not appear to be a temporary phenomenon, as diffuse $\beta$-amyloid peptide deposits turn into plaque about 9 months after ischemic episode (43). After ischemiareperfusion brain injury, the $\beta$-amyloid peptide arises as a result of neuronal ischemic damage (34), and it is likely that this peptide with its own neurotoxic activity further affects ischemic neurons.

\section{In humans}

Examination of human ischemic brains has shown that ischemia is associated with the accumulation of $\beta$-amyloid peptide in brain tissue (44-46). Studies have 
shown both diffuse and senile $\beta$-amyloid peptide plaques in areas of the brain prone to ischemia, at arterial border zones and cortex after focal and global cerebral ischemia (44-46). The middle layers of the cerebral cortex, which are very susceptible to ischemic injury, were most commonly affected by amyloid (44-46). The number of amyloid plaques in brain tissue correlated positively with age (44-46). In brains after global cerebral ischemia with a survival of up to 1 month, strong staining of the $\beta$-amyloid peptide in neurons and perivascular areas was found (45). The staining of neurons depended on the area of the brain. Neurons from the cerebral cortex and hippocampus were the most intensely stained. The ependymal and epithelial cells were also stained on the $\beta$-amyloid peptide. Not all brains had senile amyloid plaques in the cerebral cortex. The cerebral white and gray matter vessels were surrounded by $\beta$-amyloid peptide deposits. Deposits in the perivascular space looked like cuffs. In some brains, the walls of the meningeal and cortical vessels were stained for the $\beta$-amyloid peptide. Accumulation of amyloid in the perivascular blood vessel space of the blood-brain barrier suggested that the $\beta$-amyloid peptide was derived from blood. Some evidence to support this hypothesis comes from clinical studies showing that the $\beta$-amyloid peptide in the blood has been elevated in patients after ischemic brain injury $(22,47)$. According to another study, $\beta$-amyloid peptides $1-40$ and $1-42$ staining were found in the human hippocampus after ischemia (21). This intense staining of various $\beta$-amyloid peptides may contribute to the progression of ischemic hippocampus neurodegeneration.

In the brains of patients after global cerebral ischemia caused by cardiac arrest, the immunostaining of the receptor for advanced glycation end products was located both in the cells of the choroid plexus epithelium and in the ependymal cells bordering the brain ventricles (48). These cells form both the cerebrospinal fluid-brain barrier and the blood-cerebrospinal fluid barrier. The $\beta$-amyloid peptide was noted by staining in the blood vessels of the choroid plexus and in the basal membrane of the choroid plexus epithelium (48). The data showed that the choroid plexus epithelium and the lining cells, equipped with a receptor for advanced glycation end products, play not only a significant role in the accumulation of the $\beta$-amyloid peptide in the brain parenchyma but also are a place where amyloid can be removable.

After ischemic brain injury in humans due to cardiac arrest, approximately 70-fold increase in beta-amyloid peptide 1-42 in the serum was found (22). The level of amyloid growth correlated negatively with the complete clinical outcome after ischemic brain injury, which in turn probably reflects the severity of ischemic damage (22). The data confirm that brain ischemia may play a key role in the amyloidogenic processing of the amyloid protein precursor.

\section{TAU PROTEIN STAINING, PHOSPHORYLATION, AND BLOOD LEVEL AFTER BRAIN ISCHEMIA}

Although there has been significant progress recently in research on the pathogenicity of the tau protein in Alzheimer's disease, the basic molecular processes associated with the tau protein that affect neurodegeneration after ischemic brain trauma have not been finally clarified. In this analysis, we show that both 
ischemia-reperfusion brain damage and the permeability of the blood-brain barrier after ischemia induce tau protein dysfunction. As a result, we suggest that modifications of the tau protein by phosphorylation are dangerous for microtubule activity, especially in neurons, and are involved in the development of irreversible neuropathology in the ischemic brain with Alzheimer's disease dementia.

\section{In animals}

Early experimental studies documented tau protein staining in neuronal and glial cells in the hippocampus, thalamus, and cortex after permanent and focal brain ischemia $(36,49-53)$. The modified tau protein was also observed in microglial cells both in ischemic penumbra and in brain tissue, respectively, after focal and global cerebral ischemia $(29,54)$. The above data showed that some neuronal and glial cells had changes in the tau protein after ischemic brain damage (52), which may be the main pathological stage of ischemic processes in these cells (53). Another study revealed that tau protein alone can block the transport of amyloid protein precursor in neurons, which leads to the accumulation of the amyloid protein precursor in the body of neuronal cells (55).

Studies have also shown that the phosphorylation patterns of tau protein differed in different models of cerebral ischemia (32). The tau protein was dephosphorylated after total and focal cerebral ischemia $(51,52,56)$. During total brain ischemia, the tau protein was dephosphorylated, and during recirculation, it was re-phosphorylated and accumulated in the brain tissue (56). Transient local ischemic brain injury in rats with 24 -h recirculation induces site-specific hyperphosphorylation of tau protein (57). An experimental combination of reversible total brain ischemia with hyperhomocysteinemia resulted in an approximate 700-fold increase in the number of hyperphosphorylated positive tau protein neurons in the cerebral cortex compared to control conditions (31). Recent studies indicate that following brain ischemia, hyperphosphorylated tau protein in cortical neurons is integrated with apoptosis $(24,27,29,30,54,57,58)$. Khan et al. (30) showed an increase in the production of paired helical filaments of tau protein after forebrain ischemia in mice. Wen et al. $(24,57,58)$ provided evidence that brain ischemia with recirculation is involved in neurofibrillary tangle-like development after local ischemic cerebral injury. Finally, tau protein dysfunction, a typical hallmark of Alzheimer's disease, worsens experimental ischemic brain damage via tau protein-mediated iron export (59) and excitotoxicity depending on the tau protein $(28,60)$.

\section{In humans}

Early studies have shown that tau protein staining in neurons and glia is present in the hippocampus, thalamus, and cerebral cortex in the human brain after ischemia (61-63). The modified tau protein was also observed in microglial cells (63). It was noted that microglial cells' tau protein passes independent of phosphorylation modification following cerebral ischemia with recirculation in humans (63). Finally, in one of the studies, many neurofibrillary tangle-bearing neurons were observed in the nucleus basalis of Meynert ipsilateral to a massive focal cerebral infarction (23). 
Tau protein was detected in human plasma after complete ischemic brain injury with two peaks after 2 and 4 days, which probably indicates the degree of neuronal damage after ischemia-reperfusion episode (25). The observed bimodal changes in the tau protein in the blood are consistent with the 2 types of neuronal death: first, by necrosis, and second, by delayed neuronal death (26). The presented research suggests that the increase in blood tau protein can be used as a biomarker to assess neurological damage to the brain after ischemia $(25,26)$.

\section{mRNAs ASSOCIATED WITH THE AMYLOID PROTEIN PRECURSOR AFTER BRAIN ISCHEMIA}

Due to the fact that there are some new data in the literature in human and animal studies regarding changes in amyloid protein precursor following ischemiareperfusion brain damage in this part of the review, we present the first steps in mRNA studies related to the metabolism of the amyloid protein precursor after various types of brain ischemia. This indicates that there is urgent need for data on the new causative pathological role of amyloid in cerebral ischemia, which molecule presumably has an irreversible effect on the post-ischemic outcome.

\section{mRNA of the amyloid protein precursor}

After experimental focal ischemic brain damage with reperfusion, the mRNA level of the amyloid protein precursor increased both in the core and in the penumbra, by 150 and $200 \%$, respectively, in 1 week of recirculation $(64,65)$. In addition, after permanent local ischemic brain injury without recirculation, the mRNA domain of the Kunitz-type protease inhibitor domain-containing amyloid protein precursor in the cortex of the brain was induced for 3 weeks (66). Also after transient local cerebral ischemia, the amyloid protein precursors, 770 and $751 \mathrm{mRNAs}$, were induced within 1 week of recirculation (67). In addition, $1 \mathrm{~h}$ after local ischemic brain damage in ovariectomized rats, the increased mRNA level of the amyloid protein precursor was observed in ischemic brain structures (64). In contrast, estrogen treatment reduces the mRNA level of the amyloid protein precursor in the ischemic brain (64). These data suggest that estrogen therapy can be used to lower the mRNA of the amyloid protein precursor after the ischemic episode.

\section{mRNA of enzymes metabolizing the amyloid protein precursor}

The amyloid protein precursor is metabolized by $\alpha$-secretase, and this process is a non-amyloidogenic process. After experimental ischemic brain injury, the level of $\alpha$-secretase mRNA decreases $(68,69)$. The second process is called amyloidogenic process, and the amyloid protein precursor is metabolized by $\beta$-secretase and $\gamma$-secretase to produce the $\beta$-amyloid peptide (70). Some studies have demonstrated that ischemic episode of the brain activates the production and activity of $\beta$-secretase after ischemia (71-74). Another study showed changes in mRNA levels of three enzymes that metabolize the amyloid protein precursor: $\beta$-secretase, 
cathepsin B, and glutaminyl cyclase, which increased in the cortex and hippocampus after ischemia (75).

Three days after ischemic brain injury, the highest level of presenilin 1 mRNA was observed in the neuronal cells of CA3 area of the hippocampus (76). This observation suggests that an elevated level of presenilin 1 mRNA probably is associated with the response of neuronal cells to ischemia. In another study, the increased level of presenilin 1 mRNA showed the maximum growth in the striatum, cortex, and hippocampus after focal ischemic brain damage (77). In the above study, the increased level of presenilin 1 mRNA was greater on the side opposite to local ischemic brain injury. This observation may reflect the disappearance of brain neurons on the ipsilateral side. The mRNA of presenilin 1, which increased after brain ischemia $(76,77)$, is involved in the production of the $\beta$-amyloid peptide by the $\gamma$-secretase complex $(70,78)$. The above data will help understand the progressive neuronal disappearance following the ischemiareperfusion episode of the brain and the slow, prolonged accumulation of the $\beta$-amyloid peptide in ischemic brain tissue (16).

\section{EXPRESSION OF GENES INVOLVED IN THE PRODUCTION OF AMYLOID AFTER BRAIN ISCHEMIA}

The ischemic-reperfusion episode of the brain is undoubtedly one of the most common multifactorial forms of neurodegeneration, including many pathological processes occurring during ischemia and recirculation and gradually spreading to various areas of the brain. It seems that the ischemic event in humans and animals is associated with the development of Alzheimer's disease type of neurodegenerative pathology, such as the accumulation of all parts of the amyloid protein precursor after its processing in the amyloidogenic process and dysregulation of Alzheimer's disease-related genes involved in this process. Progress in understanding new proteomic and genomic processes caused by ischemic brain damage in various brain structures that have not yet been fully elucidated will result in new strategies for the treatment of neurodegeneration of the Alzheimer's disease type with full-blown dementia due to ischemia.

\section{CA1 area of the hippocampus and medial temporal cortex}

In the CAl region of the hippocampus and temporal cortex, the expression of the amyloid protein precursor gene was below the control value within 2 days after ischemia $(79,80)$. In the above areas, 7 and 30 days after cerebral ischemia-reperfusion, the expression of the amyloid protein precursor gene was above the control value $(79,80)$. The expression of the $\beta$-secretase gene increased above the control value following brain ischemia injury in the CA1 area of the hippocampus 2 to 7 days after recirculation (79). But, 30 days after brain ischemia, the expression of the $\beta$-secretase gene was below the control value (79). The expression of the $\beta$-secretase gene was above the control value in the temporal cortex after 2 days from ischemic episode (80). The expression of the $\beta$-secretase gene was reduced in the temporal cortex 7 and 30 days after 
ischemia (80). In the CAl region, the expression of the presenilin 1 and 2 gene was increased 2 and 7 days after ischemia (79). But, 30 days post-ischemic injury, the gene expression of presenilin 1 and 2 was below the control value (79). In the temporal cortex, presenilin 1 gene expression was lowered below the control value, but presenilin 2 was above the control value 2 days after ischemia (81). Seven days after ischemia, the gene expression of presenilin 1 was reduced, and presenilin 2 was elevated (81). Thirty days post-ischemia, the expression of presenilin 1 gene was above the control value, and presenilin 2 was below the control value (81).

\section{EXPRESSION OF THE TAU PROTEIN GENE IN THE CA1 AREA AFTER BRAIN ISCHEMIA}

In the neurons of CAl area of the hippocampus, the tau protein encoding gene expression increased above the control value on the 2 nd day after brain ischemia (33). On the 7th day of reperfusion after ischemic episode, the gene expression oscillated in the range of control values (33). On the 30th day of recirculation after brain ischemia, the expression of the tau protein gene was below the control value (33). The statistical significance of changes in the expression of the tau protein gene after brain ischemia-reperfusion injury in rats was between 2 and 7 , and 2 and 30 days of recirculation (33).

\section{EXPRESSION OF GENES INVOLVED IN THE DIRECT DEATH OF NEURONS AFTER BRAIN ISCHEMIA}

One of the risk factors of Alzheimer's disease is aging, and for that reason, a large number of scientists believe that the main cause of Alzheimer's disease is brain ischemia closely related to age. It seems that brain injury caused by ischemia and reperfusion facilitates the development of irreversible neurodegeneration similar to Alzheimer's disease as a result of neuronal death, synaptic dysfunction, inflammatory changes, white matter damage, and general brain atrophy, which changes are closely related to genes involved in neuronal death in Alzheimer's disease. Despite the years of expansion, the amyloid Alzheimer's disease theory has not solved the etiology of the disorder (82), and the current research suggests that brain ischemia leads to neurodegeneration of Alzheimer's disease through numerous terminal events, such as dysregulation of genes that cause cell death in various brain structures of varying intensity. Understanding the basic pathological pathways causing proteomic and genomic changes associated with Alzheimer's disease and induced by cerebral ischemia will help in the development of neurodegenerative dementia treatment after ischemia.

\section{CA1 area of the hippocampus}

Expression of the autophagy gene in the CAl region of the hippocampus after brain ischemia with 2,7 , and 30 days of recirculation was within the control 
limits (83). Two days after ischemic brain injury, the expression of the mitophagy gene in the CAl region increased above the control value. Seven and 30 days after ischemia-reperfusion injury of the brain, the gene expression was within the control range. Overexpression of the caspase 3 gene in the CAl region was observed after 2 and 7 days of recirculation. However, 30 days after ischemic brain injury, the gene expression was below the control value.

\section{Medial temporal cortex}

Two days after ischemic brain injury, autophagy gene expression increased above the control value in the medial temporal cortex (84). However, 7 and 30 days after ischemia-reperfusion brain injury, autophagy gene expression decreased. Two days after cerebral ischemia, mitophagy gene expression decreased below the control value (84). Nevertheless, 7 and 30 days after ischemic brain injury, the expression of the mitophagy gene increased above the control value. Two days after cerebral ischemia, the expression of caspase 3 gene decreased below the control value (84). However, 7 and 30 days after brain injury due to ischemia and reperfusion, caspase 3 gene expression increased above the control value.

\section{THE RELATIONSHIP BETWEEN IRON DYSHOMEOSTASIS AND AMYLOIDOGENESIS}

Both the amyloid protein precursor and iron play a key role in brain neurodegeneration due to Alzheimer's disease and cerebral ischemia (59, 85-88). Alzheimer's disease is primarily characterized by the deposition of amyloid plaques and the formation of neurofibrillary tangles which co-localize with iron (88). Under physiological conditions, the amyloid protein precursor is processed primarily on the non-amyloidogenic pathway by $\alpha$-secretase, thereby producing the neuroprotective ectodomain of the soluble amyloid protein precursor $\alpha$ and the carboxyterminal fragment $\alpha$. Alternatively, a small pool of amyloid protein precursor is processed by the amyloidogenic pathway using $\beta$-secretase, thereby producing a soluble amyloid protein precursor $\beta$ and carboxy-terminal fragment $\beta$. The carboxy-terminal fragment $\beta$ is further cleaved by $\gamma$-secretase, resulting in $\beta$-amyloid peptides.

Iron is gradually deposited in selected areas of the brain during Alzheimer's disease, as well as in the course of ischemic neurodegeneration $(59,85-88)$. In the brain, iron is present in neurons, oligodendrocytes, astroglia, and microglia cells. Excess iron is associated with oxidative stress and neuronal damage because iron accumulation in neurons can cause free radical production and mitochondrial dysfunction and ultimately lead to neuronal death. In addition, iron can induce hyperphosphorylation and aggregation of tau protein. Deficiency of tau protein leads to iron accumulation, which is associated with impaired transport of the amyloid protein precursor to the cell membrane $(59,87)$. Therefore, iron accumulation in brain cells must be strictly regulated to maintain basic cellular function and avoid cytotoxicity. The evidence obtained confirms the role of the amyloid protein precursor in maintaining iron homeostasis 
in brain tissue (86). It has been demonstrated that the amyloid protein precursor and soluble amyloid protein precursor $\alpha$ facilitate iron outflow by stabilizing the iron exporter ferroportin 1 on the cell membrane $(86,87)$. In contrast, ablation of the amyloid protein precursor in neurons causes iron retention (87), while the knockout of the amyloid protein precursor in mice causes iron accumulation in the brain (86). While the amyloid protein precursor affects iron export, the inverse is also true because iron modulates the metabolism of the amyloid protein precursor (86). Iron and interleukin 1 levels in cells regulate translation of the amyloid protein precursor by acting on an iron-responsive element found in the 5' untranslated region of the amyloid protein precursor mRNA $(87,89)$. Iron has also been shown to affect the processing of the amyloid protein precursor and the production of $\beta$-amyloid peptides. In addition, the activation of $\alpha$-secretase and $\beta$-secretase is proteolytically modulated by furin; furin protein levels are reduced under conditions of excess iron, which promotes $\beta$-secretase activity, thereby promoting amyloidogenesis (87). Iron and inflammation promote amyloid toxicity (87). Recent experimental studies showed that: (i) iron overload increased retention in the neurons of the soluble amyloid protein precursor $\alpha$, (ii) iron overload reduced the extracellular levels of the soluble amyloid protein precursor $\alpha$ and $\beta$-amyloid peptide, and (iii) the direct molecular target of iron is $\beta$-secretase (86).

Given the key physiological and pathological role of the amyloid protein precursor and its cleavage products in the brain, it is likely that iron overload may affect neuronal activity, interfering with the normal processing of the amyloid protein precursor. Although it is unclear what mechanism causes abnormal intracellular retention of the soluble amyloid protein precursor $\alpha$, there is evidence that cell accumulation of the soluble amyloid protein precursor $\alpha$ may be due to intracellular cleavage of the amyloid protein precursor by $\alpha$ secretase or the internalization of the extracellular soluble amyloid protein precursor $\alpha$ by cell surface receptors $(90,91)$. Together, evidence of the beneficial role of the secreted soluble amyloid protein precursor $\alpha$ indicates that iron overload mediates the decrease in secreted soluble amyloid protein precursor $\alpha$, which can lead to harmful consequences. This possibility is particularly important in neurological diseases, given that the secretion of the soluble amyloid protein precursor $\alpha$ affects many brain disorders, including Alzheimer's disease and cerebral ischemia (85-88). In addition, it has recently been suggested that the loss of $\beta$-amyloid peptide function, rather than its accumulation, plays a pathogenic role in Alzheimer's disease (92). In summary, iron overload affected nonamyloidogenic as well as amyloidogenic metabolism of the neuronal amyloid protein precursor. In addition, it was confirmed that the soluble amyloid protein precursor $\alpha$ is an endogenous inhibitor of $\beta$-secretase activity, potentially affecting the production of $\beta$-amyloid peptide (86). As iron directly inhibits $\beta$-secretase activity, it is likely that increased iron primarily inhibits $\beta$-secretase and the amyloidogenic pathway and promotes the non-amyloidogenic pathway and retention of the soluble amyloid protein precursor $\alpha$. $\beta$-secretase activity is then inhibited by the growth of the soluble amyloid protein precursor $\alpha$ (86). These abnormal iron-induced changes form a vicious circle that leads to dysregulation of the processing of amyloid protein precursors in neurons. 


\section{CONCLUSION}

Although there are reasonable doubts about the effects of cerebral ischemia on the development of Alzheimer's disease, the mounting evidence on the ischemic theory of Alzheimer's disease should not be ignored. Ignoring the numerous scientifically substantiated clinical and experimental data on the connection between brain ischemia and Alzheimer's disease will hamper not only the proper understanding of the disease mechanism but also the development of complementary and alternative strategies for the treatment and management of Alzheimer's disease. The conclusions drawn from the study of ischemia-induced Alzheimer's disease-associated proteins and their genes in the hippocampus and the medial temporal cortex, which contribute to the death of neurons, the production of the $\beta$-amyloid peptide, and neurofibrillary tangle-like formation, are important for the development of treatment goals in the therapy of Alzheimer's disease. As deposits of amyloid and tau protein may not be the cause in the pathogenesis of Alzheimer's disease, further research is needed in this field. Animal models of cerebral ischemia seem to be a useful experimental approach in determining the role of folding proteins and their genes in the neurodegenerative process of sporadic Alzheimer's disease.

Acknowledgments: The authors acknowledge the financial support from the following institutions: the Mossakowski Medical Research Centre, Polish Academy of Sciences, Warsaw, Poland (T3-RP) and the Medical University of Lublin, Lublin, Poland (DS 475/19-SJC).

Conflict of interest: The authors declare no potential conflicts of interest with respect to research, authorship, and/or publication of this chapter.

Copyright and Permission Statement: To the best of our knowledge, the materials included in this chapter do not violate copyright laws. All original sources have been appropriately acknowledged and/or referenced. Where relevant, appropriate permissions have been obtained from the original copyright holder(s).

\section{REFERENCES}

1. Salminen A, Kauppinen A, Kaarniranta K. Hypoxia/ischemia activate processing of amyloid precursor protein: Impact of vascular dysfunction in the pathogenesis of Alzheimer's disease. J Neurochem. 2017;140:536-49. http://dx.doi.org/10.1111/jnc.13932

2. Pluta R. Brain ischemia: Alzheimer's disease mechanisms. New York: Nova Science Publishers, Inc.; 2019. 311 p.

3. Pluta R, Jabłoński M, Ułamek-Kozioł M, Kocki J, Brzozowska J, Januszewski S, et al. Sporadic Alzheimer's disease begins as episodes of brain ischemia and ischemically dysregulated Alzheimer's disease genes. Mol Neurobiol. 2013;48:500-15. http://dx.doi.org/10.1007/s12035-013-8439-1

4. Pluta R, Ułamek-Kozioł M, Czuczwar SJ. Brain ischemia: Alzheimer's disease mechanisms. New York: Nova Science Publishers, Inc.; 2019. Chapter XII, Shared genomic and proteomic contribution to brain ischemia and Alzheimer's disease: Ischemic etiology of Alzheimer's disease. p. 209-49. 
5. Kiryk A, Pluta R, Figiel I, Mikosz M, Ułamek M, Niewiadomska G, et al. Transient brain ischemia due to cardiac arrest causes irreversible long-lasting cognitive injury. Behav Brain Res. 2011;219:1-7. http://dx.doi.org/10.1016/j.bbr.2010.12.004

6. De la Tremblaye PB, Plamondon H. Impaired conditioned emotional response and object recognition are concomitant to neuronal damage in the amygdale and perirhinal cortex in middle-aged ischemic rats. Behav Brain Res. 2011;219:227-233. http://dx.doi.org/10.1016/j.bbr.2011.01.009

7. Li J, Wang YJ, Zhang M, Fang CQ, Zhou HD. Cerebral ischemia aggravates cognitive impairment in a rat model of Alzheimer's disease. Life Sci. 2011;89:86-92. http://dx.doi.org/10.1016/j.1fs.2011.04.024

8. Brainin M, Tuomilehto J, Heiss WD, Bornstein NM, Bath PM, Teuschl Y, et al. Post Stroke Cognition Study Group. Post-stroke cognitive decline: An update and perspectives for clinical research. Eur J Neurol. 2015;22:229-38. http://dx.doi.org/10.1111/ene.12626

9. Cohan CH, Neumann JT, Dave KR, Alekseyenko A, Binkert M, Stransky K, et al. Effect of cardiac arrest on cognitive impairment and hippocampal plasticity in middle-aged rats. PLoS One. 2015;10:e0124918. http://dx.doi.org/10.1371/journal.pone.0124918

10. Surawan J, Areemit S, Tiamkao S, Sirithanawuthichai T, Saensak S. Risk factors associated with poststroke dementia: A systematic review and meta-analysis. Neurol Int. 2017;9:7216. http://dx.doi. org/10.4081/ni.2017.7216

11. Bivard A, Lillicrap T, Maréchal B, Garcia-Esperon C, Holliday E, Krishnamurthy V, et al. Transient ischemic attack results in delayed brain atrophy and cognitive decline. Stroke. 2018;49:384-90. http://dx.doi.org/10.1161/STROKEAHA.117.019276

12. Kim JH, Lee Y. Dementia and death after stroke in older adults during a 10-year follow-up: Results from a competing risk model. J Nutr Health Aging. 2018;22:297-301. http://dx.doi.org/10.1007/ s12603-017-0914-3

13. Snowdon DA, Greiner LH, Mortimer JA, Riley KP, Greiner PA, Markesbery WR. Brain infarction and the clinical expression of Alzheimer disease: The Nun Study. JAMA. 1997;277:813-17. http://dx.doi. org/10.1001/jama.1997.03540340047031

14. Hossmann KA, Schmidt-Kastner R, Grosse Ophoff B. Recovery of integrative central nervous function after one hour global cerebro-circulatory arrest in normothermic cat. J Neurol Sci. 1987;77:305-20. http://dx.doi.org/10.1016/0022-510X(87)90130-4

15. Pluta R. The role of apolipoprotein $E$ in the deposition of $\beta$-amyloid peptide during ischemia-reperfusion brain injury. A model of early Alzheimer's disease. Ann N Y Acad Sci. 2000;903:324-34. http:// dx.doi.org/10.1111/j.1749-6632.2000.tb06383.x

16. Pluta R, Ułamek M, Jabłoński M. Alzheimer's mechanisms in ischemic brain degeneration. Anat Rec. 2009;292:1863-81. http://dx.doi.org/10.1002/ar.21018

17. Pluta R, Januszewski S, Jabłoński M, Ułamek M. Factors in creepy delayed neuronal death in hippocampus following brain ischemia-reperfusion injury with long-term survival. Acta Neurochir. 2010;106(Suppl.):37-41. http://dx.doi.org/10.1007/978-3-211-98811-4_5

18. Pluta R, Ułamek M, Jabłoński M. Consideration of the ischaemic basis and treatment of Alzheimer's disease. Folia Neuropathol. 2010;48:11-26.

19. Sekeljic V, Bataveljic D, Stamenkovic S, Ułamek M, Jabłoński M, Radenovic L, et al. Cellular markers of neuroinflammation and neurogenesis after ischemic brain injury in the long-term survival rat model. Brain Struct Funct. 2012;217:411-20. http://dx.doi.org/10.1007/s00429-011-0336-7

20. Pluta R, Kida E, Lossinsky AS, Golabek AA, Mossakowski MJ, Wisniewski HM. Complete cerebral ischemia with short-term survival in rats induced by cardiac arrest: I. Extracellular accumulation of Alzheimer's $\beta$-amyloid protein precursor in the brain. Brain Res. 1994;649:323-8. http://dx.doi. org/10.1016/0006-8993(94)91081-2

21. Qi J, Wu H, Yang Y, Wand D, Chen Y, Gu Y, et al. Cerebral ischemia and Alzheimer's disease: The expression of amyloid- $\beta$ and apolipoprotein E in human hippocampus. J Alzheimers Dis. 2007;12:335-41. http://dx.doi.org/10.3233/JAD-2007-12406

22. Zetterberg H, Mörtberg E, Song L, Chang L, Provuncher GK, Patel PP, et al. Hypoxia due to cardiac arrest induces a time-dependent increase in serum amyloid $\beta$ levels in humans. PLoS One. 2011;6(12):e28263. http://dx.doi.org/10.1371/journal.pone.0028263

23. Kato T, Hirano A, Katagiri T, Sasaki H, Yamada S. Neurofibrillary tangle formation in the nucleus basalis of Meynert ipsilateral to a massive cerebral infarct. Ann Neurol. 1988;23:620-3. http://dx.doi. org/10.1002/ana.410230617 
24. Wen Y, Yang SH, Liu R, Perez EJ, Brun-Ziukemagel AM, Koulen P, et al. Cdk5 is involved in NFT-like tauopathy induced by transient cerebral ischemia in female rats. Biochim Biophys Acta. 2007;1772:473-83. http://dx.doi.org/10.1016/j.bbadis.2006.10.011

25. Mörtberg E, Zetterberg H, Nordmark J, Blennow K, Catry C, Decraemer H, et al. Plasma tau protein in comatose patients after cardiac arrest treated with therapeutic hypothermia. Acta Anaesthesiol Scand. 2011;55:1132-8. http://dx.doi.org/10.1111/j.1399-6576.2011.02505.x

26. Randall J, Mörtberg E, Provuncher GK, Fournier DR, Duffy DC, Rubertsson S, et al. Tau proteins in serum predict neurological outcome after hypoxic brain injury from cardiac arrest: Results of a pilot study. Resuscitation. 2013;84:351-6. http://dx.doi.org/10.1016/j.resuscitation.2012.07.027

27. Majd S, Power JH, Koblar SA, Grantham HJ. Early glycogen synthase kinase-3 and protein phosphatase $2 \mathrm{~A}$ independent tau dephosphorylation during global brain ischaemia and reperfusion following cardiac arrest and the role of the adenosine monophosphate kinase pathway. Eur J Neurosci. 2016;44:1987-97. http://dx.doi.org/10.1111/ejn.13277

28. Bi M, Gladbach A, van Eersel J, Ittner A, Przybyla M, van Hummel A, et al. Tau exacerbates excitotoxic brain damage in an animal model of stroke. Nat Commun. 2017;8:473. http://dx.doi.org/10.1038/ s41467-017-00618-0

29. Fujii H, Takahashi T, Mukai T, Tanaka S, Hosomi N, Maruyama H, et al. Modifications of tau protein after cerebral ischemia and reperfusion in rats are similar to those occurring in Alzheimer's disease - Hyperphosphorylation and cleavage of 4- and 3-repeat tau. J Cereb Blood Flow Metab. 2017;37:2441-57. http://dx.doi.org/10.1177/0271678X16668889

30. Khan S, Yuldasheva NY, Batten TFC, Pickles AR, Kellett KAB, Saha S. Tau pathology and neurochemical changes associated with memory dysfunction in an optimized murine model of global cerebral ischaemia - A potential model for vascular dementia? Neurochem Int. 2018;118:134-44. http:// dx.doi.org/10.1016/j.neuint.2018.04.004

31. Kovalska M, Tothova B, Kovalska L, Tatarkova Z, Kalenska D, Tomascova A, et al. Association of induced hyperhomocysteinemia with Alzheimer's disease-like neurodegeneration in rat cortical neurons after global ischemia-reperfusion injury. Neurochem Res. 2018;43:1766-78. http://dx.doi. org/10.1007/s11064-018-2592-x

32. Pluta R, Ułamek-Kozioł M, Januszewski S, Czuczwar SJ. Tau protein dysfunction after brain ischemia. J Alzheimers Dis. 2018;66:429-37. http://dx.doi.org/10.3233/JAD-180772

33. Pluta R, Bogucka-Kocka A, Ułamek-Kozioł M, Bogucki J, Kocki J, Czuczwar SJ. Ischemic tau protein gene induction as an additional key factor driving development of Alzheimer's phenotype changes in CAl area of hippocampus in an ischemic model of Alzheimer's disease. Pharmacol Rep. 2018;70: 881-4. http://dx.doi.org/10.1016/j.pharep.2018.03.004

34. Ishimaru H, Ishikawa K, Haga S, Shoji M, Ohe Y, Haga C, et al. Accumulation of apolipoprotein $\mathrm{E}$ and $\beta$-amyloid-like protein in a trace of the hippocampal CAl pyramidal cell layer after ischaemic delayed neuronal death. Neuro Rep. 1996;7:3063-7. http://dx.doi.org/10.1097/ 00001756-199611250-00054

35. Lin B, Schmidt-Kastner R, Busto R, Ginsberg MD. Progressive parenchymal deposition of $\beta$-amyloid precursor protein in rat brain following global cerebral ischemia. Acta Neuropathol. 1999;97:359-68. http://dx.doi.org/10.1007/s004010050999

36. Sinigaglia-Coimbra R, Cavalheiro EA, Coimbra CG. Postischemic hyperthermia induces Alzheimerlike pathology in the rat brain. Acta Neuropathol. 2002;103:444-52. http://dx.doi.org/10.1007/ s00401-001-0487-3

37. Jabłoński M, Maciejewski R, Januszewski S, Ułamek M, Pluta R. One year follow up in ischemic brain injury and the role of Alzheimer factors. Physiol Res. 2011;60(Suppl. 1):S113-19.

38. Banati RB, Gehrmann J, Wießner C, Hossmann KA, Kreutzberg GW. Glial expression of the $\beta$-amyloid precursor protein (APP) in global ischemia. J Cereb Blood Flow Metab. 1995;15:647-54. http:// dx.doi.org/10.1038/jcbfm.1995.80

39. Palacios G, Mengod G, Tortosa A, Ferrer I, Palacios JM. Increased $\beta$-amyloid precursor protein expression in astrocytes in the gerbil hippocampus following ischaemia: Association with proliferation of astrocytes. Eur J Neurosci. 1995;7:501-10. http://dx.doi.org/10.1111/j.1460-9568.1995.tb00346.x

40. Nihashi T, Inao S, Kajita Y, Kawai T, Sugimoto T, Niwa M, et al. Expression and distribution of beta amyloid precursor protein and beta amyloid peptide in reactive astrocytes after transient middle cerebral artery occlusion. Acta Neurochir. 2001;143:287-95. http://dx.doi.org/10.1007/s007010170109 
41. Badan I, Platt D, Kessler C, Popa-Wagner A. Temporal dynamics of degenerative and regenerative events associated with cerebral ischemia in aged rats. Gerontology. 2003;49:356-65. http://dx.doi. org/10.1159/000073763

42. Badan I, Dinca I, Buchhold B, Suofu Y, Walker L, Gratz M, et al. Accelerated accumulation of $\mathrm{N}$ - and C-terminal beta APP fragments and delayed recovery of microtubule-associated protein 1B expression following stroke in aged rats. Eur J Neurosci. 2004;19:2270-80. http://dx.doi. org/10.1111/j.0953-816X.2004.03323.x

43. Van Groen T, Puurunen K, Maki HM, Sivenius J, Jolkkonen J. Transformation of diffuse beta-amyloid precursor protein and beta-amyloid deposits to plaques in the thalamus after transient occlusion of the middle cerebral artery in rats. Stroke. 2005;36:1551-6. http://dx.doi.org/10.1161/01. STR.0000169933.88903.cf

44. Jendroska K, Poewe W, Daniel SE, Pluess J, Iwerssen-Schmidt H, Paulsen J, et al. Ischemic stress induces deposition of amyloid beta immunoreactivity in human brain. Acta Neuropathol. 1995;90:461-6. http://dx.doi.org/10.1007/BF00294806

45. Wiśniewski HM, Maślińska D. Beta-protein immunoreactivity in the human brain after cardiac arrest. Folia Neuropathol. 1996;34:65-71.

46. Jendroska K, Hoffmann OM, Patt S. Amyloid $\beta$ peptide and precursor protein (APP) in mild and severe brain ischemia. Ann N Y Acad Sci. 1997;826:401-5. http://dx.doi.org/10.1111/j.1749-6632.1997. tb48492.x

47. Lee PH, Bang OY, Hwang EM, Lee JS, Joo US, Mook-Jung I, et al. Circulating beta amyloid peptide is elevated in patients with acute ischemic stroke. J Neurol Transm. 2005;112:1371-9. http://dx.doi. org/10.1007/s00702-004-0274-0

48. Maślińska D, Laure-Kamionowska M, Taraszewska A, Deręgowski K, Maśliński S. Immunodistribution of amyloid beta protein (A $\beta$ ) and advanced glycation end-product receptors (RAGE) in choroid plexus and ependyma of resuscitated patients. Folia Neuropathol. 2011;49:295-300.

49. Dewar D, Graham DI, Teasdale GM, McCulloch J. Alz-50 and ubiquitin immunoreactivity is induced by permanent focal cerebral ischaemia in the cat. Acta Neuropathol. 1993;86:623-9. http://dx.doi. org/10.1007/BF00294302

50. Dewar D, Graham DI, Teasdale GM, McCulloch J. Cerebral ischemia induces alterations in tau and ubiquitin proteins. Dementia. 1994;5:168-73. http://dx.doi.org/10.1159/000106716

51. Geddes JW, Schwab C, Craddock S, Wilson JL, Pettigrew LC. Alterations in tau immunostaining in the rat hippocampus following transient cerebral ischemia. J Cereb Blood Flow Metab. 1994;14:554-64. http://dx.doi.org/10.1038/jcbfm.1994.69

52. Dewar D, Dawson D. Tau protein is altered by focal cerebral ischaemia in the rat: An immunohistochemical and immunoblotting study. Brain Res. 1995;684:70-8. http://dx.doi. org/10.1016/0006-8993(95)00417-O

53. Irving EA, Yatsushiro K, McCulloch J, Dewar D. Rapid alteration of tau in oligodendrocytes after focal ischemic injury in the rat: Involvement of free radicals. J Cereb Blood Flow Metab. 1997;17:612-22. http://dx.doi.org/10.1097/00004647-199706000-00003

54. Majd S, Power JH, Koblar SA, Grantham HJM. Introducing a developed model of reversible cardiac arrest to produce global brain ischemia and its impact on microtubule-associated protein tau phosphorylation at Ser396. Int J Neurol Neurother. 2016;3:040. http://dx.doi.org/10.23937/2378-3001/3/1/1040

55. Stamer K, Vogel R, Thies E, Mandelkow E, Mandelkow EM. Tau blocks traffic of organelles, neurofilaments, and APP vesicles in neurons and enhances oxidative stress. J Cell Biol. 2002;156:1051-63. http://dx.doi.org/10.1083/jcb.200108057

56. Mailliot C, Podevin-Dimster V, Rosenthal RE, Sergeant N, Delacourte A, Fiskum G, et al. Rapid tau protein dephosphorylation and differential rephosphorylation during cardiac arrest-induced cerebral ischemia and reperfusion. J Cereb Blood Flow Metab. 2000;20:543-9. http://dx.doi. org/10.1097/00004647-200003000-00013

57. Wen Y, Yang S, Liu R, Simpkins JW. Transient cerebral ischemia induces site-specific hyperphosphorylation of tau protein. Brain Res. 2004;1022:30-8. http://dx.doi.org/10.1016/j.brainres.2004.05.106

58. Wen Y, Yang S, Liu R, Brun-Zinkernagel AM, Koulen P, Simpkins JW. Transient cerebral ischemia induces aberrant neuronal cell cycle re-entry and Alzheimer's disease-like tauopathy in female rats. J Biol Chem. 2007;279:22684-92. http://dx.doi.org/10.1074/jbc.M311768200 
59. Tuo QZ, Lei P, Jackman KA, Li XL, Xiong H, Li XL, et al. Tau mediated iron export prevents ferroptotic damage after ischemic stroke. Mol Psychiatry. 2017;22:1520-30. http://dx.doi.org/10.1038/ mp.2017.171

60. Pluta R, Salińska E, Puka M, Stafiej A, Lazarewicz JW. Early changes in extracellular amino acids and calcium concentrations in rabbit hippocampus following complete 15-min cerebral ischemia. Resuscitation. 1988;16:193-210. http://dx.doi.org/10.1016/0300-9572(88)90046-9

61. Uchihara T, Tsuchiya K, Kondo H, Hayama T, Ikeda K. Widespread appearance of Alz-50 immunoreactive neurons in the human brain with cerebral infarction. Stroke. 1995;26:2145-8. http://dx.doi. org/10.1161/01.STR.26.11.2145

62. Irving EA, Nicoll J, Graham DI, Dewar D. Increased tau immunoreactivity in oligodendrocytes following human stroke and head injury. Neurosci Lett. 1996;213:189-92. http://dx.doi. org/10.1016/0304-3940(96)12856-1

63. Uchihara T, Nakamura A, Arai T, Ikeda K, Tsuchiya K. Microglial tau undergoes phosphorylation independent modification after ischemia. Glia. 2004;45:180-7. http://dx.doi.org/10.1002/glia.10318

64. Shi J, Panickar KS, Yang SH, Rabbani O, Day AL, Simpkins JW. Estrogen attenuates over-expression of beta-amyloid precursor protein messenger RNA in an animal model of focal ischemia. Brain Res. 1998;810:87-92. http://dx.doi.org/10.1016/S0006-8993(98)00888-9

65. Shi J, Yang SH, Stubley L, Day AL, Simpkins JW. Hypoperfusion induces overexpression of $\beta$-amyloid precursor protein mRNA in a focal ischemic rodent model. Brain Res. 2000;853:1-4. http://dx.doi. org/10.1016/50006-8993(99)02113-7

66. Abe K, Tanzi RE, Kogure K. Selective induction of Kunitz-type protease inhibitor domain-containing amyloid precursor protein mRNA after persistent focal ischemia in rat cerebral cortex. Neurosci Lett. 1991;125:172-4. http://dx.doi.org/10.1016/0304-3940(91)90020-T

67. Koistinaho J, Pyykonen I, Keinanen R, Hokfelt T. Expression of $\beta$-amyloid precursor protein mRNAs following transient focal ischaemia. Neuro Rep. 1996;7:2727-31. http://dx.doi. org/10.1097/00001756-199611040-00064

68. Nalivaeva NN, Fisk L, Kochkina EG, Plesneva SA, Zhuravin IA, Babusikova E, et al. Effect of hypoxia/ ischemia and hypoxic preconditioning/reperfusion on expression of some amyloid-degrading enzymes. Ann N Y Acad Sci. 2004;1035:21-33. http://dx.doi.org/10.1196/annals.1332.002

69. Yan FL, Zhang J, Guan XN, Hong Z. mRNA expression and activity of ADAMl7 in hippocampus after chronic cerebral hypoperfusion: Experiment with aged rats. Zhonghua Yi Xue Za Zhi. 2007;87:2515-17.

70. Pluta R, Furmaga-Jabłońska W, Maciejewski R, Ułamek-Kozioł M, Jabłoński M. Brain ischemia activates $\beta$ - and $\gamma$-secretase cleavage of amyloid precursor protein: Significance in sporadic Alzheimer's disease. Mol Neurobiol. 2013;47:425-34. http://dx.doi.org/10.1007/s12035-012-8360-z

71. Blasko I, Beer R, Bigl M, Apelt J, Franz G, Rudzki D, et al. Experimental traumatic brain injury in rats stimulates the expression, production and activity of Alzheimer's disease $\beta$-secretase (BACE-1). J Neural Transm. 2004;111:523-36. http://dx.doi.org/10.1007/s00702-003-0095-6

72. Chen XH, Siman R, Iwata A, Meaney DF, Trojanowski JQ, Smith DH. Long-term accumulation of amyloid- $\beta, \beta$-secretase, presenilin- 1 , and caspase- 3 in damaged axons following brain trauma. Am J Pathol. 2004;165:357-71. http://dx.doi.org/10.1016/S0002-9440(10)63303-2

73. Wen Y, Onyewuchi O, Yang S, Liu R, Simpkins JW. Increased beta-secretase activity and expression in rats following transient cerebral ischemia. Brain Res. 2004;1009:1-8. http://dx.doi.org/10.1016/j. brainres.2003.09.086

74. Chuang CM, Hsieh CL, Lin HY, Lin JG. Panax Notoginseng Burk attenuates impairment of learning and memory functions and increases ED1, BDNF and beta-secretase immunoreactive cells in chronic stage ischemia-reperfusion injured rats. Am J Chin Med. 2008;36:685-93. http://dx.doi.org/10.1142/ S0192415X08006156

75. Ye J, Pi R, Mao X, Chen X, Qin J, Xu S, et al. Alterations in mRNA expression of BACEl, cathep$\sin$ B, and glutaminyl cyclase in mice ischemic brain. Neuro Rep. 2009;20:1456-60. http://dx.doi. org/10.1097/WNR.0b013e328332024a

76. Tanimukai H, Imaizumi K, Kudo T, Katayama T, Tsuda M, Takagi T, et al. Alzheimer-associated presenilin-l gene is induced in gerbil hippocampus after transient ischemia. Mol Brain Res. 1998;54: 212-18. http://dx.doi.org/10.1016/S0169-328X(97)00337-9 
77. Pennypacker KR, Hernandez H, Benkovic S, Morgan DG, Willing AE, Sanberg PR. Induction of presenilins in the rat brain after middle cerebral arterial occlusion. Brain Res Bull. 1999;48:539-43. http:// dx.doi.org/10.1016/S0361-9230(99)00031-3

78. Polavarapu R, An J, Zhang C, Yepes M. Regulated intramembrane proteolysis of the low-density lipoprotein receptor-related protein mediates ischemic cell death. Am J Pathol. 2008;172:1355-62. http:// dx.doi.org/10.2353/ajpath.2008.070975

79. Kocki J, Ułamek-Kozioł M, Bogucka-Kocka A, Januszewski S, Jabłoński M, Gil-Kulik P, et al. Dysregulation of amyloid precursor protein, $\beta$-secretase, presenilin 1 and 2 genes in the rat selectively vulnerable CAl subfield of hippocampus following transient global brain ischemia. J Alzheimers Dis. 2015;47:1047-56. http://dx.doi.org/10.3233/JAD-150299

80. Pluta R, Kocki J, Ułamek-Kozioł M, Petniak A, Gil-Kulik P, Januszewski S, et al. Discrepancy in expression of $\beta$-secretase and amyloid- $\beta$ protein precursor in Alzheimer-related genes in the rat medial temporal lobe cortex following transient global brain ischemia. J Alzheimers Dis. 2016;51:1023-31. http://dx.doi.org/10.3233/JAD-151102

81. Pluta R, Kocki J, Ułamek-Kozioł M, Bogucka-Kocka A, Gil-Kulik P, Januszewski S, et al. Alzheimerassociated presenilin 2 gene is dysregulated in rat medial temporal lobe cortex after complete brain ischemia due to cardiac arrest. Pharmacol Rep. 2016;68:155-61. http://dx.doi.org/10.1016/j. pharep.2015.08.002

82. Jack CR, Bennett DA, Blennow K, Carrillo MC, Dunn B, Haeberlein SB, et al. NIA-AA research framework: Toward a biological definition of Alzheimer's disease. Alzheimers Dement. 2018;14:535-62. http://dx.doi.org/10.1016/j.jalz.2018.02.018

83. Ułamek-Kozioł M, Kocki J, Bogucka-Kocka A, Januszewski S, Bogucki J, Czuczwar SJ, et al. Autophagy, mitophagy and apoptotic gene changes in the hippocampal CAl area in a rat ischemic model of Alzheimer's disease. Pharmacol Rep. 2017;69:1289-94. http://dx.doi.org/10.1016/j. pharep.2017.07.015

84. Ułamek-Kozioł M, Kocki J, Bogucka-Kocka A, Petniak A, Gil-Kulik P, Januszewski S, et al. Dysregulation of autophagy, mitophagy, and apoptotic genes in the medial temporal lobe cortex in an ischemic model of Alzheimer's disease. J Alzheimers Dis. 2016;54:113-21. http://dx.doi.org/10.3233/ JAD-160387

85. Eid R, Arab NTT, Greenwood MT. Iron mediated toxicity and programmed cell death: A review and a re-examination of existing paradigms. Biochim Biophys Acta Mol Cell Res 2017;1864:399-430. http://dx.doi.org/10.1016/j.bbamcr.2016.12.002

86. Chen Y, Chen W, Huang X, Xu Y, Zhang H. Iron dysregulates APP processing accompanying with sAPP $\alpha$ cellular retention and $\beta$-secretase inhibition in rat cortical neurons. Acta Pharmacol Sin. 2018;39:177-83. http://dx.doi.org/10.1038/aps.2017.113

87. Masaldan S, Bush AI, Devos D, Rolland AS, Moreau C. Striking while the iron is hot: Iron metabolism and ferroptosis in neurodegeneration. Free Radic Biol Med. 2019;133:221-33. http://dx.doi. org/10.1016/j.freeradbiomed.2018.09.033

88. Ndayisaba A, Kaindlstorfer C, Wenning GK. Iron in neurodegeneration - Cause or consequence? Front Neurosci. 2019;13:180. http://dx.doi.org/10.3389/fnins.2019.00180

89. Bandyopadhyay S, Rogers JT. Alzheimer's disease therapeutics targeted to the control of amyloid precursor protein translation: Maintenance of brain iron homeostasis. Biochem Pharmacol. 2014;88: 486-94. http://dx.doi.org/10.1016/j.bcp.2014.01.032

90. Kounnas MZ, Moir RD, Rebeck GW, Bush AI, Argraves WS, Tanzi RE, et al. LDL receptor-related protein, a multifunctional ApoE receptor, binds secreted beta-amyloid precursor protein and mediates its degradation. Cell. 1995;82:331-40. http://dx.doi.org/10.1016/0092-8674(95)90320-8

91. Shin RW, Saido TC, Maeda M, Kitamoto T. Novel alpha-secretase cleavage of Alzheimer's amyloid beta precursor protein in the endoplasmic reticulum of COS7 cells. Neurosci Lett. 2005;376:14-19. http:// dx.doi.org/10.1016/j.neulet.2004.11.032

92. Kepp KP. Alzheimer's disease due to loss of function: A new synthesis of the available data. Prog Neurobiol. 2016;143:36-60. http://dx.doi.org/10.1016/j.pneurobio.2016.06.004 